\title{
PEMBEDAAN ILMU HUKUM EMPIRIS \\ DAN ILMU HUKUM NORMATIF
}

\section{Oleh: \\ Dr. Azwar Agus, SH, M.Hum \\ (Dosen Tetap FH Universitas Tamansiswa Palembang)}

\section{A. Pendahuluan}

Ada suatu kecenderungan bahwa penelitian hukum seringkali dikaitkan dengan suatu penelitian empiris, karena hal tersebut mencakup beberapa aspek yang saling bersesuaian. Dalam kenyataannya proses penelitian hukum lebih rumit dari apa yang dibayangkan, terlebih lagi yang diteliti ilmu hukum. Semua penelitian secara esensial merupakan suatu proses yang mencakup pemilihan-pemilihan dalam berbagai tahapan. Metode-metode yang ada biasanya dikombinasikan melalui berbagai cara dalam proses penelitian tersebut ${ }^{1}$. Oleh karenanya biasanya dipergunakan lebih dari satu metode dalam melakukan penelitian, misalnya metode pengamatan seringkali dipergunkan pula metode wawancara dan lain sebagainya. Untuk itu sebelum kita melakukan penellaahan Pembedaan Ilmu Hukum Empiris dengan Ilmu Hukum Normatif terlebih dahulu harus mengetahui Karakter Ilmu Hukum itu sendiri. Permasalahan pokok yang sering menjadi kendala dalam penulisan ilmu hukum adalah dengan mengkaitkan ilmu hukum dengan penelitian sosilogis. Hal ini masih menjadi perdebatan dikalangan para ahli dan masing-masing mempunyai argumentasi sendiri. Untuk memahami persoalan hukum diperlukan suatu pendekatan (metode) guna mencapai suatu derajat keilmuan hukum secara hakiki.

Hukum merupakan suatu aturan yang dianggap sebagai suatu ketentuan yang harus dipatuhi bersama. Hukum juga mempunyai tujuan, salah satunya untuk memberikan ketentraman dan kebahagiaan. Namun demikian walaupun hukum itu mempunyai tujuan tetapi hukum tidak selamanya dapat diamati dan diukur. Hukum tumbuh dan berkembang dalam masyarakat sehingga masyarakatlah yang membentuk hukum, mempertahankan dan mengembangkan hukum. Secara tidak langsung ada keterkaitan antara masyarakat dengan hukum. Disinilah letak karakteristik ilmu hukum, karena hukum itu hidup, berkembang dan mengikuti perkembangan zaman. Selain itu, ilmu hukum memiliki karakter yang khas (sui generis). Salah satu kekhasan ilmu hukum yaitu dari sifatnya yang normatif. Objek ilmu hukum adalah hukum sedangkan hukum adalah norma sosial yang didalamnya sarat akan

${ }^{1}$ Soerjono Soekanto "Perspektif Teoritis Studi Hukum dalam Masyarakat" Rajawali - Jakarta (1984), hal.81. 
nilai/norma-norma. Oleh karena itulah ilmu hukum tidak dapat digolongkan kedalam ilmu sosial karena ilmu sosial hanya berkaitan dengan kebenaran empirik semata ${ }^{2}$.

\section{B. Permasalahan}

Adapun permasalahan dalam tulisan ini adalah Bagaimana Pembedaan Ilmun Hukum Empiris dan Ilmu Hukum Normatif?

\section{Pembahasan}

Ilmu Hukum sebagai ilmu yang sui generis, artinya ilmu hukum merupakan jenis ilmu sendiri. Dikatakan jenis sendiri karena limu hukum dengan kualitas ilmiah sulit dikelompokkan dalam salah satu cabang pohon ilmu. Ilmu membimbing aktifitas manusia dalam pembangunan, baik fisik maupun non fisik ${ }^{3}$.

Ciri yang demikian menyebabkan sementara kalangan yang tidak memahami kepribadian ilmu hukum itu mulai meragukan hakikat keilmuan hukum. Keraguan itu disebabkan karena dengan sifat nomatif ilmu hukum bukanlah ilmu empiris. Disisi lain para ahli hukum Indonesia berusaha untuk mengangkat derajat keilmuan hukum dengan mengempiriskan ilmu hukum melalui kajian sosiologis. Inilah yang menjadi sumber "salahpaham" dalam usaha pengembangan ilmu hukum di Indonesia. Hal ini semakin membuat tidak jelas arah pendidikan hukum di Indonesia.

Salah satu upaya untuk mengilmiahkan ilmu hukum secara empiris adalah dengan menerapkan metode penelitian dalam kajian hukum normatif. Metode ilmu sosial dapat digunakan dalam penelitiaan dasar yang memandang hukum sebagai fenomena sosial. Kajian ilmu hukum diempiriskan dengan merumuskan format penelitian hukum yang dilatarbelakangi oleh metode penelitian sosial. Dengan demikian, maka akan ditemukan format penelitian ilmu sosial dalam penelitian hukum normatif. Perbedaan antara penelitian kualitatif dan kuantitatif adalah pada sifat data. Oleh karenanya, penelitian yang menggunakan data seyogyanya penelitian empiris. Selain itu seringkali kita menggunakan dua pendekatan dalam metode kajian ilmu hukum, yaitu: pendekatan dari sudut filsafat ilmu dan pendekatan dari sudut pandang teori hukum.

Filsafat ilmu membedakan ilmu dari sudut pandang positivistik yang melahirkan ilmu empiris dan pandangan normatif yang melahirkan ilmu normatif. Dari dua pandangan ini ilmu

\footnotetext{
${ }^{2}$ Prof. Dr. Meter Mahmud Marzuki, SH, MS, LL.M “Penelitian Hukum” Kencana Prenada Media Group, Yakarta, hal.10.

${ }^{3}$ Drs. Rizal Mustansyir, M.Hum., Drs. Misanl Munir, M.Hum "Filsafat Ilmu" Pustaka Pelajar, Yogyakarta, hal.173.
} 
hukum sesuai dengan karakter aslinya yaitu sebagai ilmu yang normatif dan disisi lain memiliki karakter empiris (sociological jurisprudence \& socio legal jurisprudence). Sehingga seringkali ilmu hukum dibedakan atas ilmu hukum normatif dan ilmu hukum empiris.

Dari sudut pandang Teori Hukum, dibagi atas tiga lapisan utama yaitu: Dogmatik Hukum, Teori Hukum (dalam arti sempit) dan Filsafat Hukum ${ }^{4}$. Ketiga lapisan tersebut pada prakteknya saling memberi dukungan dan memiliki karakteristik khas yang dengan sendirinya mempunyai metode yang khas pula dan hal inilah yang sering dikenal sebagai bidang kajian Teori Hukum.

Dengan mengetahui pendekatan-pendekatan tersebut diatas, sangatlah tidak tepat bila kita lebih mementingkan/mengutamakan penelitian hukum empiris dan mengenyampingkan penelitian hukum normatif.

D.H.M. Meuwessen ${ }^{5}$ membedakan ilmu hukum normatif dengan ilmu hukum empiris, yaitu :

1. Ilmu hukum empiris secara tegas membedakan fakta dari norma;

2. Bagi ilmu hukum empiris, gejala hukum harus murni empiris, yaitu fakta sosial;

3. Bagi ilmu hukum empiris, metode yang digunakan adalah metode ilmu empiris;

4. Ilmu hukum empiris merupakan ilmu yang bebas nilai.

Sedangkan J.J.H. Bruggink ${ }^{6}$, menggambarkan perbedaan antara ilmu hukum empiris dengan ilmu hukum normatif dengan tabel gambar sebagai berikut :

\begin{tabular}{|l|l|l|}
\hline \multicolumn{1}{|c|}{$\begin{array}{c}\text { Pandangan positivistik: } \\
\text { Ilmu hukum empirik }\end{array}$} & \multicolumn{1}{|c|}{$\begin{array}{c}\text { Pandangan normatif: } \\
\text { Ilmu hukum normatif }\end{array}$} \\
\hline Hubungan dasar & Subyek - obyek & Subyek - obyek \\
\hline Sikap ilmuwan & Penonton (toeschouwer) & Participan (doelnemer) \\
\hline PERSPEKTIF & EKSTERN & INTERN \\
\hline Proposisi Kebenaran & Korespondensi & Pragmatik \\
\hline Metode & Hanya informatif atau empiris & Normatif dan evaluatif \\
\hline Moral & $\begin{array}{l}\text { Hanya Metode yang biasa } \\
\text { diamati panca indra }\end{array}$ & Juga metode lain \\
\hline
\end{tabular}

${ }^{4}$ Philipus M Hadjon, Tatik Sri Djatmiati “Argumentasi Hukum” Gajah Mada University Press, Surabaya, hal 3.

${ }^{5}$ Ibid., hal 7 .

${ }^{6}$ Ibid., hal 8. 


\begin{tabular}{|l|l|l|}
\hline $\begin{array}{l}\text { Hubungan antar } \\
\text { moral dan hukum }\end{array}$ & Pemisahan tegas & Tidak ada pemisahan \\
\hline Ilmu & $\begin{array}{l}\text { Hanya sosiologi hukum empiris } \\
\text { dan teori hukum empiris }\end{array}$ & $\begin{array}{l}\text { Ilmu hukum dalam arti } \\
\text { luas }\end{array}$ \\
\hline
\end{tabular}

\section{Kesimpulan.}

Dari yang dikemukakan diatas, kiranya dapat disimpulkan :

1. Dalam kajian normatif sebaiknya berpegang pada tradisi ilmu hukum, sedangkan kajian empiris sebaiknya menggunakan metode penelitian empiris pula;

2. Sudah seharusnya tidak mengempiriskan segi normatif ilmu hukum dan sebaliknya juga tidak menormatifkan segi empiris dalam kajian hukum, karena ilmu hukum yang mempunyai karakteristik tersendiri (sui generis);

3. Perbedaan ilmu hukum hukum normatif dan empiris adalah dari hubungan dasar sikap ilmuwan tentang teori kebenaran. Dalam ilmu hukum empiris sikap ilmuwan adalah sebagai penonton yang mengamati gejala-gejala yang obyeknya dapat ditangkap pancaindra. Sedangkan ilmu hukum normatif, yuris secara aktif menganalisis norma, sehingga peranan subyek sangat menonjol;

4. Dari kebenaran ilmiah, ilmu hukum empiris adalah suatu kebenaran korespondensi, yaitu segala sesuatu itu benar apabila didukung oleh data dan fakta, sedangkan Ilmu hukum normatif dasar kebenarannya adalah pragmatik yang pada umumnya merupakan kesepakatan dari para ahli hukum itu sendiri.

\section{DAFTAR PUSTAKA}

Peter Mahmud Marzuki, "Penelitian Hukum” Kencana Prenada Media Group, Yogyakarta (2006).

Philipus M Hadjon, Tatik Sri Djatmiati “Argumentasi Hukum” Gajah Mada University Press, Yogyakarta (2005).

Rizal Mustansyir., Misnal Munir., "Filsafat Ilmu” Pustaka Pelajar, Yogyakarta (2004).

Soerjono Soekanto., “Perspektif Teoritis Studi Hukum dalam Masyarakat" Rajawali Jakarta (1984) 